\title{
Sodium Toxicity: Should NaOH Be Substituted by KOH in Plant Tissue Culture?
}

\author{
Oumar Doungous ${ }^{1 *}$, Jameel M. Al-Khayri ${ }^{2}$ and Modeste Kan Kouassi ${ }^{3}$ \\ ${ }^{1}$ The Central and West African Virus Epidemiology (WAVE), Biotechnology Laboratory, Ekona Regional Research Centre, \\ Institute of Agricultural Research for Development, Yaoundé, Cameroon, ${ }^{2}$ Department of Agricultural Biotechnology, College \\ of Agriculture and Food Sciences, King Faisal University, Al-Ahsa, Saudi Arabia, ${ }^{3}$ The Central and West African Virus \\ Epidemiology (WAVE), Plant Tissue Culture Laboratory, Pôle Scientifique et d'Innovation de Bingerville, Université Félix \\ Houphouët-Boigny, Abidjan, Côte d'Ivoire
}

Keywords: $\mathrm{NaOH}$ toxicity, $\mathrm{KOH}$, medium $\mathrm{pH}$ adjustment, dissolution of growth regulators, nutrient imbalance

\section{INTRODUCTION}

Plant tissue culture is an attractive system that involves growing cells, tissues and organs of plants on artificial media under a controlled environment, with applications in food production through crop improvement and plant conservation. Plant tissue culture is also an important tool for the continuous production of active compounds including secondary metabolites and engineered molecules (Espinosa-Leal et al., 2018). Many tissue culture techniques exist and are used in research institutions as well as in commercial laboratories. One of the most important factors in plant tissue culture is the medium which is a defined formulation of inorganic salts and organic compounds providing nutrients to the cultured explants (George and de Klerk, 2008). The optimum nutrient concentration is a critical determinant for the growth and morphogenesis of tissues and the accumulation of secondary metabolites (Murthy et al., 2014).

Different culture media varying in the composition and level of macronutrients and micronutrients were developed, among which Murashige and Skoog medium or modifications from this formulation are the widely used for plant tissue culture (Murashige and Skoog, 1962; Phillips and Garda, 2019). Plant tissue culture media also contain some or all of the following components: vitamins, amino acids or nitrogen supplements, carbon source, undefined natural organic supplements, growth regulators and solidifying agents. Therefore, knowledge of the nutritional requirements of cultured cells, tissues and organs is important for choosing the most appropriate culture medium for the explant used and the targeted plant species, cultivar and genotype (Al-Khayri, 2011; Orlowska et al., 2021).

Most of in vitro culture studies were based on the types and concentrations of growth regulators which play a key role in determining the development pathway of plant cells and tissues (Amiri and Mohammadi, 2021; Mitrofanova et al., 2021). Considering that cells sensitivity to plant growth regulators may be affected by the mineral composition, studies across a wide range of species and applications have focused on the selection or the manipulation of basal salt composition for the optimization of the nutrient component for a particular response (Ramage and Williams, 2002; Niedz and Evens, 2007; Akin et al., 2017; Silva et al., 2019; Elyazid et al., 2021; Raji and Siril, 2021). Due to the diverse nutrition requirements of specific species, genotypes, developmental steps and the many interactions of the chemical nutrients, a number of approaches were developed for the estimation of the correct concentration balance of mineral nutrients and the optimization or customization of the medium. These approaches range from factorial or triangular method and response surface methodology to recent machine learning techniques (Khvatkov et al., 2019; Hameg et al., 2020; Hesami and Jones, 2020; Kabylbekova et al., 2020). 
Another important factor for plant tissue culture is medium $\mathrm{pH}$. It has a remarkable effect on the development of explants. It regulates the equilibrium at the cellular membrane level and controls the solubility and absorption of ions. Moreover, $\mathrm{pH}$ plays an important role in the solidification of the medium. As a rule of thumb, initial medium $\mathrm{pH}$ is adjusted to the value between 5.5-6.0 (Thorpe et al., 2008). An adjustment to the optimal value of the $\mathrm{pH}$ has to be done for almost all the media with alkali $(\mathrm{NaOH}$ or $\mathrm{KOH})$ if the $\mathrm{pH}$ is low, or with acid $(\mathrm{HCl})$ in case of high $\mathrm{pH}$.

$\mathrm{NaOH}$ is also used for the preparation of stock solution of growth regulators in plant tissue culture. The toxicity of $\mathrm{Na}$ has been proven in vivo and in vitro in many studies, and most basic culture media are deprived from it. However, the negative effects of $\mathrm{Na}$ on mineral nutrition, morphogenesis and differentiation are largely unknown. In addition, no study has compared the effects of $\mathrm{NaOH}$ and $\mathrm{KOH}$ in plant tissue culture. Here we address the hypothesis that $\mathrm{NaOH}$ induces ion toxicity and nutritional imbalance. We argue that adjusting the $\mathrm{pH}$ of the medium and dissolving growth regulators with $\mathrm{KOH}$ instead of $\mathrm{NaOH}$ may be more beneficial for plant cell, tissue, and organ culture.

\section{SODIUM IN TISSUE CULTURE MEDIUM}

Based on ecological considerations for survival and reproduction, $\mathrm{Na}$ is defined as a non-essential element for higher plants but has been shown to be essential for certain C4 plant species (Kronzucker et al., 2013; Krishnasamy et al., 2014). Most macronutrient formulations do not contain $\mathrm{Na}$ at all (Table 1). Only small amounts are incorporated into the media from the micronutrient components (Poothong et al., 2018). Even though $\mathrm{Na}$ is not considered as a major element, it can be added to the medium from other sources such as gelling agents used for medium solidification, or $\mathrm{NaOH}$ used for medium $\mathrm{pH}$ adjustment and for preparation of stock solution of growth regulators.

$\mathrm{NaOH}$ is one of the solvents used for the preparation of stock solution of cytokinins and auxins (naphthalene acetic acid, 2,4 dichlorophenoxy acetic acid, and indol acetic acid). Generally, vitamins, amino acids, auxins, gibberellins and abscisic acid render the culture medium more acidic. Moreover, ascorbic acid or citric acid added to many media to control oxidative browning (Salazar-Vega et al., 2022) also lower the medium pH. Therefore, a $\mathrm{pH}$ adjustment to 5.5-6.0 with an alkali solution is needed. In most cases, this adjustment is done by adding $\mathrm{NaOH}$ to the medium (Shi et al., 2017). The lower the medium $\mathrm{pH}$ value, the higher the concentration of $\mathrm{NaOH}$ needed to increase the $\mathrm{pH}$. Consequently, the use of $\mathrm{NaOH}$ either for dissolution of growth regulators or for $\mathrm{pH}$ adjustment increases the optimal $\mathrm{Na}^{+}$concentrations initially defined for the medium. For apple tissue culture, Shi et al. (2017) demonstrated that adjustment of $\mathrm{pH}$ from 5.1 (initial) to 6.0 by adding $\mathrm{NaOH}$ leads to the significant increase in $\mathrm{Na}^{+}$concentration. Furthermore, the $\mathrm{Na}$ may not be depleted easily from the culture medium and higher concentrations and activities of $\mathrm{Na}^{+}$can cause salt stress.

\section{SALT STRESS}

$\mathrm{Na}^{+}$is not required for many physiological and biochemical processes (Isayenkov and Maathuis, 2019). It is required only at the micronutrient level even for halophytes where $\mathrm{Na}$ is clearly beneficial if not essential (Krishnasamy et al., 2014; Yuan et al., 2019). Although under soil conditions low levels of $\mathrm{Na}^{+}$can stimulate plant growth or other functions especially under $\mathrm{K}^{+}$ deficiency (Maathuis, 2014; Ferreira et al., 2020), this situation could not be applied in plant tissue culture due to the presence of potassium as macroelement in culture media (Table 1).

Salt stress reduces water uptake, leading to cell dehydration and changes in cell turgor, inducing osmotic stress. In the long term, accumulation of $\mathrm{Na}$ to toxic levels induces ionic toxicity leading to $\mathrm{Ca}^{2+}, \mathrm{Mg}^{2+}$ and $\mathrm{K}^{+}$deficiency and to other nutrient imbalances (Munns and Tester, 2008; Hamani et al., 2021). Salt stress impairs growth both at whole plant and cellular level by low osmotic potential, nutritional imbalance, specific ion effect, or a combination of these factors.

In plant tissue culture, $\mathrm{NaOH}$ is not considered among the factors affecting the availability of nutrients and components of the medium. Although addition of $\mathrm{NaOH}$ for $\mathrm{pH}$ adjustment leads to the decrease in $\mathrm{Mg}^{2+}$ and $\mathrm{Ca}^{2+}$ concentration in the apple culture medium due to precipitation (Shi et al., 2017). Thus, in vitro cultures may be adversely affected by $\mathrm{NaOH}-$ induced nutritional disorders since it has been demonstrated that the concentrations and ratio of certain nutrients can affect the sensitivity of cells to growth regulators and other component of the medium as well as morphogenesis and differentiation (Leifert et al., 1995; Oberschelp and Goncalves, 2018). Nutrient deficiency or imbalance can cause abnormal physiological responses in plant cultures such as hyperhydricity, callus formation and necrosis (Reed et al., 2013; Teixeira da Silva et al., 2020). Additionally, plant cells and tissues performance may also be adversely affected by the alteration of metabolic pathways and osmotic adjustments. This is particularly important for protoplasts which are difficult to culture and are particularly useful to address essential biological questions regarding salt stress response (Gilliard et al., 2021).

The responses of plants to assess stress tolerance were commonly proven using in vitro stress assays. Most of these studies exposed plants to very high stress levels and scored very pronounced phenotypes such as germination rate, seedling survival, the development of visual symptoms such as bleaching or the induction of established stress markers (Skirycz et al., 2010; Claeys et al., 2014). Moreover, $\mathrm{Na}^{+}$toxicity was tested with the interference of $\mathrm{Cl}^{-}$toxicity, thus producing equivocal results (Genc et al., 2016). However, studies on the effect of salt stress in plant tissue culture have not received much attention and perhaps by overlooking or not considering $\mathrm{Na}^{+}$from $\mathrm{NaOH}$. This $\mathrm{Na}^{+}$ is not negligible and is likely to induce stress due to the fact that plant responses to salinity are complex and many reports confirmed that low stress levels can severely limit shoot growth without leading to other visible stress phenotypes (Claeys et al., 2014). Therefore, a better understanding of $\mathrm{Na}$ requirements of cultured cells and tissues, the role of $\mathrm{Na}$ on altered patterns of 
TABLE 1 | Components and concentrations of $\mathrm{Na}$ and $\mathrm{K}$ in commonly used plant tissue culture basal media.

\begin{tabular}{|c|c|c|c|c|c|c|c|}
\hline Basal medium & MS & B5 & WPM & DKW & SH & KC & vW \\
\hline \multicolumn{8}{|c|}{ Macronutrient components of $\mathrm{K}$ and $\mathrm{Na}\left(\mathrm{mg} \mathrm{L}^{-1}\right)$} \\
\hline $\mathrm{KNO}_{3}$ & 1,900 & 2,500 & - & - & 2,500 & - & 525 \\
\hline $\mathrm{K}_{2} \mathrm{SO}_{4}$ & - & - & 990 & 1,559 & - & - & - \\
\hline $\mathrm{KH}_{2} \mathrm{PO}_{4}$ & 170 & - & 170 & 265 & - & 250 & 250 \\
\hline $\mathrm{KCl}$ & - & - & - & - & - & 250 & - \\
\hline $\mathrm{NaH}_{2} \mathrm{PO}_{4} \cdot \mathrm{H}_{2} \mathrm{O}$ & - & 150 & - & - & - & - & - \\
\hline \multicolumn{8}{|c|}{ Micronutrient components of $\mathrm{K}$ and $\mathrm{Na}\left(\mathrm{mg} \mathrm{L}^{-1}\right)$} \\
\hline $\mathrm{KI}$ & 0.83 & 0.75 & - & - & 1 & - & - \\
\hline $\mathrm{Na}_{2} \mathrm{MoO}_{4} \cdot 2 \mathrm{H}_{2} \mathrm{O}$ & 0.25 & 0.25 & 0.25 & 0.39 & 0.1 & - & - \\
\hline $\mathrm{Na}_{2}$ EDTA & 37.3 & 37.3 & 37.3 & 45.4 & 20 & - & - \\
\hline \multicolumn{8}{|c|}{ Molar concentration (mM) } \\
\hline $\mathrm{K}^{+}$ & 20.04 & 24.72 & 12.61 & 19.84 & 25.23 & 5.19 & 7.03 \\
\hline $\mathrm{Na}^{+}$ & 0.20 & 1.45 & 0.20 & 0.24 & 0.11 & 0 & 0 \\
\hline
\end{tabular}

Basal media were selected according to Phillips and Garda (2019). MS, Murashige and Skoog; B5, Gamborg; WPM, Woody Plant Medium; DKW, Driver and Kuniyuki Woody; SH, Schenk and Hildebrandt; KC, Knudson C Orchid; VW, Vacin and Went.

mineral nutrition, morphogenesis and differentiation of plant tissues is needed.

\section{THE CHOICE OF KOH IN REPLACING $\mathrm{NaOH}$}

Studies on alkali might detect the negative effects of $\mathrm{NaOH}$, improve media composition and in vitro protocols and contribute to the selection of most appropriate alkali solution for medium $\mathrm{pH}$ adjustment and dissolution of growth regulators. We can anticipate that adjusting medium $\mathrm{pH}$ and dissolving growth regulators with $\mathrm{KOH}$ instead of $\mathrm{NaOH}$ may be more beneficial for plant tissue culture, especially glycophytes, which include the vast majority of crop plants.

The choice of $\mathrm{KOH}$ in this note is due to multiple important attributes of this product. $\mathrm{KOH}$ is an alkali that is also used for medium $\mathrm{pH}$ adjustment in plant tissue culture (Elyazid et al., 2021). It can also be used for dissolution of growth regulators. There are chemical and structural similarities between $\mathrm{Na}^{+}$and $\mathrm{K}^{+}$in hydrated form (Isayenkov and Maathuis, 2019), thereby $\mathrm{KOH}$ can fulfill biophysical, physiological and biochemical processes achieved by $\mathrm{NaOH} . \mathrm{K}^{+}$is the only monovalent cation in plant cells which is essential for most higher plants and important for many enzymatic reactions, ionic and $\mathrm{pH}$ homeostasis, and maintenance of adequate membrane potential (Ahmad and Maathuis, 2014; Assaha et al., 2017). Potassium is among the chemicals whose increments have a positive effect on plant quality and growth parameters such as length or number of shoots (Poothong and Reed, 2015; Hunková et al., 2020). $\mathrm{KOH}$ has other advantages in that when higher concentrations are added to the medium, it is possible to adjust the additional amounts from multiple macronutrient components of potassium (Table 1). The average concentration of potassium of $13.6 \mathrm{mM}$ was noticed in almost all culture media and the most common value (median) is $10.5 \mathrm{mM}$ (George and de Klerk, 2008).

\section{CONCLUDING REMARKS AND FUTURE PERSPECTIVES}

$\mathrm{NaOH}$ is commonly used for medium $\mathrm{pH}$ adjustment and for preparation of stock solution of growth regulators in plant tissue culture. As the use of $\mathrm{NaOH}$ will increase the initial concentration of $\mathrm{Na}^{+}$from 0 or micromolar level to millimolar level in the culture medium, it is important to analyze the physiological, biochemical and molecular aspects of $\mathrm{Na}^{+}, \mathrm{K}^{+}$and other ions uptake, sequestration, and transport in different protocols of in vitro cultures. An assessment of the effects of $\mathrm{NaOH}$ on nutrient availability, media optimization and development of in vitro cultures of different tissues/organs/genotypes is needed. Further approaches for the estimation of the correct concentration balance of mineral nutrients, modeling and the optimization of the medium should also take into consideration the $\mathrm{Na}$ derived from $\mathrm{NaOH}$. As many studies reported the importance of potassium in managing the alkalinity problem, this assessment must also take into account $\mathrm{KOH}$ in view of selecting the appropriate alkali for each specific in vitro tissue culture. Since less is known on the relationship between mineral uptake and morphogenesis, we hope that this opinion article will also stimulate more investigations into the relationship between mineral uptake, transport, metabolism, and morphogenesis. Lastly, in addition to the commonly known soil salinity concept that is a major thread to agriculture, we believe that this communication can open a new concept of abiotic stresses affecting morphogenesis and differentiation of in vitro-grown plant cells, tissues and organs.

\section{AUTHOR CONTRIBUTIONS}

The manuscript was prepared by OD and reviewed by JA-K and MK. All authors contributed to the article and approved the submitted version. 


\section{FUNDING}

This work was supported, in whole or in part, by the Bill \& Melinda Gates Foundation and The United Kingdom Foreign, Commonwealth \& Development Office (FCDO) under Grant Number OPP1212988/INV-002969 to the Central and West African Virus Epidemiology (WAVE) Program for root and tuber crops - through a subgrant from Université Félix Houphouët-Boigny (UFHB) to the Institute of Agricultural

\section{REFERENCES}

Ahmad, I., and Maathuis, F. J. M. (2014). Cellular and tissue distribution of potassium: physiological relevance, mechanisms and regulation. J. Plant Physiol. 171, 708-714. doi: 10.1016/j.jplph.2013.10.016

Akin, M., Eyduran, E., Niedz, R. P., and Reed, B. M. (2017). Developing hazelnut tissue culture medium free of ion confounding. Plant Cell Tiss. Organ. Cult. 130, 483-494. doi: 10.1007/s11240-017-1238-Z

Al-Khayri, J. M. (2011). Basal salt requirements differ according to culture stage and cultivar in date palm somatic embryogenesis. Am. J. Biochem. Biotechnol. 7, 32-42. doi: 10.3844/ajbbsp.2011.32.42

Amiri, S., and Mohammadi, R. (2021). Establishment of an efficient in vitro propagation protocol for Sumac (Rhus coriaria L.) and confirmation of the genetic homogeneity. Scientific Rep. 11:173. doi: 10.1038/s41598-020-80550-4

Assaha, D. V. M., Ueda, A., Saneoka, H., Al-Yahyai, R., and Yaish, M. W. (2017). The role of $\mathrm{Na}^{+}$and $\mathrm{K}^{+}$transporters in salt stress adaptation in glycophytes. Front. Physiol. 8:509. doi: 10.3389/fphys.2017.00509

Claeys, H., Van Landeghem, S., Dubois, M., Maleux, K., and Inzé, D. (2014). What is stress? Dose-response effects in commonly used in vitro stress assays. Plant Physiol. 165, 519-527. doi: 10.1104/pp.113.234641

Elyazid, D. M. A., Salama, A. -M., Zanaty, A. F. M. E., and Abdalla, N. (2021). In vitro propagation and acclimatization of banana plants: antioxidant enzymes, chemical assessments and genetic stability of regenerates as a response to copper sulphate. Plants 10:1853. doi: 10.3390/plants10091853

Espinosa-Leal, C. A., Puente-Garza, C. A., and García-Lara, S. (2018). In vitro plant tissue culture: means for production of biological active compounds. Planta. 248, 1-18. doi: 10.1007/s00425-018-2910-1

Ferreira, J. F. S., da Silva Filho, J. B., Liu, X., and Sandhu, D. (2020). Spinach plants favor the absorption of $\mathrm{K}^{+}$over $\mathrm{Na}^{+}$regardless of salinity, and may benefit from $\mathrm{Na}^{+}$when $\mathrm{K}^{+}$is deficient in the soil. Plants. 9:507. doi: 10.3390/plants9040507

Genc, Y., Oldach, K., Taylor, J., and Lyons, G. H. (2016). Uncoupling of sodium and chloride to assist breeding for salinity tolerance in crops. New Phytol. 210, 145-156. doi: 10.1111/nph.13757

George, E. F., and de Klerk, G. J. (2008). The components of plant tissue culture media I: Macro- and micro-nutrients. In: Plant propagation by tissue culture. 3rd edition, Volume 1, The background, ed. E. F. George, M. A. Hall, G. -J de Klerk (Springer, Dordrecht, The Netherlands) p. 65-113. doi: 10.1007/978-1-4020-5005-3_3

Gilliard, G., Huby, E., Cordelier, S., Ongena, M., Dhondt-Cordelier, S., and Deleu, M. (2021). Protoplast: a valuable toolbox to investigate plant stress perception and response. Front. Plant Sci. 12:749581. doi: 10.3389/fpls.202 1.749581

Hamani, A. K. M., Chen, J., Soothar, M. K., Wang, G., Shen, X., Gao Y., et al. (2021). Application of exogenous protectants mitigates salt-induced $\mathrm{Na}^{+}$toxicity and sustains cotton (Gossypium hirsutum L.) seedling growth: comparison of glycine betaine and salicylic acid. Plants 10, 380. doi: 10.3390/plants10020380

Hameg, R., Arteta, T. A., Landin, M., Gallego, P. P., and Barreal, M. E. (2020). Modeling and optimizing culture medium mineral composition for in vitro propagation of Actinidia arguta. Front. Plant Sci. 11:554905. doi: 10.3389/fpls.2020.554905

Hesami, M., and Jones, A. M. P. (2020). Application of artificial intelligence models and optimization algorithms in plant cell and tissue culture. Appl. Microbiol. Biotechnol. 104, 9449-9485. doi: 10.1007/s00253-020-10888-2
Research for Development (IRAD). Under the grant conditions of the Foundation, a Creative Commons Attribution 4.0 Generic License has already been assigned to the Author Accepted Manuscript that might arise from this submission.

\section{ACKNOWLEDGMENTS}

We are grateful to Rachid Hanna and colleagues for comments on earlier versions of the manuscript.

Hunková, J., Gajdošová, A., and Szabóová, M. (2020). Effect of mesos component $\left(\mathrm{MgSO}_{4}, \mathrm{CaCl}_{2}, \mathrm{KH}_{2} \mathrm{PO}_{4}\right)$ on in vitro shoot growth of blackberry, blueberry, and Saskatoon. Plants 9:935. doi: 10.3390/plants9080935

Isayenkov, S. V., and Maathuis, F. J. M. (2019). Plant salinity stress: many unanswered questions remain. Front. Plant Sci. 10:80. doi: $10.3389 /$ fpls.2019.00080

Kabylbekova, B., Kovalchuk, I., Mukhitdinova, Z., Turdiyev, T., Kairova, G., Madiyeva, G., et al. (2020). Reduced major minerals and increased minor nutrients improve micropropagation in three apple cultivars. In Vitro Cell. Dev. Biol-Plant 56, 335-349. doi: 10.1007/s11627-019-10019-1

Khvatkov, P., Chernobrovkina, M., Okuneva, A., and Dolgov, S. (2019). Creation of culture media for efficient duckweeds micropropagation (Wolffia arrhiza and Lemna minor) using artificial mathematical optimization models. Plant Cell Tiss. Org. Cult. 136, 85-100. doi: 10.1007/s11240-018-1494-6

Krishnasamy, K., Bell, R., and Ma, Q. (2014). Wheat responses to sodium vary with potassium use efficiency of cultivars. Front. Plant Sci. 5:631. doi: $10.3389 /$ fpls.2014.00631

Kronzucker, H. J., Coskun, D., Schulze, L. M., Wong, J. R., and Britto, D. T. (2013). Sodium as nutrient and toxicant. Plant Soil 369, 1-23. doi: 10.1007/s11104-013-1801-2

Leifert, C., Murphy, K. P., and Lumsden, P. J. (1995). Mineral and carbohydrate nutrition of plant cell and tissue cultures. Crit. Rev. Plant Sci. 14, 83-109 doi: 10.1080/07352689509701923

Maathuis, F. J. M. (2014). Sodium in plants: perception, signalling, and regulation of sodium fluxes. J. Exp. Bot. 65, 849-858. doi: 10.1093/jxb/ert326

Mitrofanova, I., Ivanova, N., Kuzmina, T., Mitrofanova, O., and Zubkova, N. (2021). In vitro regeneration of clematis plants in the Nikita Botanical Garden via somatic embryogenesis and organogenesis. Front. Plant Sci. 12:541171, doi: $10.3389 /$ fpls.2021.541171

Munns, R., and Tester, M. (2008). Mechanisms of salinity tolerance. Annu. Rev. Plant Biol. 59, 651-681. doi: 10.1146/annurev.arplant.59.032607.092911

Murashige, T., and Skoog, F. (1962). A revised medium for rapid growth and bioassays with tobacco tissue cultures. Physiol. Plant. 15, 473-497. doi: 10.1111/j.1399-3054.1962.tb08052.x

Murthy, H. N., Lee, E. J., and Paek, K. Y. (2014). Production of secondary metabolites from cell and organ cultures: strategies and approaches for biomass improvement and metabolite accumulation. Plant Cell Tiss. Org. Cult. 118, 1-16. doi: 10.1007/s11240-014-0467-7

Niedz, R. P., and Evens, T. J. (2007). Regulating plant tissue growth by mineral nutrition. In Vitro Cell. Dev. Biol.-Plant 43, 370-381. doi: $10.1007 /$ s1 1627-007-9062-5

Oberschelp, G. P. J., and Goncalves, A. N. (2018). Analysis of nutrient deficiencies affecting in vitro growth and development of Eucalyptus dunnii Maiden. Physiol Mol. Biol. Plants 24, 693-702. doi: 10.1007/s12298-0180560-1

Orlowska, R., Zimny, J., and Bednarek, P. T. (2021). Copper ions induce DNA sequence variation in zygotic embryo culture-derived barley regenerants. Front. Plant Sci. 11:614837. doi: 10.3389/fpls.2020.614837

Phillips, G. C., and Garda, M. (2019). Plant tissue culture media and practices: an overview. In Vitro Cell. Dev. Biol. Plant. 55, 242-257. doi: 10.1007/s11627-019-09983-5

Poothong, S., Khen, T., and Chumphukam, O. (2018). In vitro mineral nutrition for improving growth and multiplication of stevia. Agri. Nat. Res. 52, 477-483. doi: 10.1016/j.anres.2018.11.007 
Poothong, S., and Reed, B. M. (2015). Increased $\mathrm{CaCl}_{2}, \mathrm{MgSO}_{4}$ and $\mathrm{KH}_{2} \mathrm{PO}_{4}$ improve the growth of micropropagated red raspberries. In Vitro Cell. Dev. Biol. Plant 51, 648-658. doi: 10.1007/s11627-015-9720-y

Raji, R., and Siril, E. A. (2021). Alteration of media enables efficient in vitro cloning of mature Elaeocarpus serratus L. (Ceylon olive): a commercially important fruit tree. Physiol. Mol. Biol. Plants 27, 429-443. doi: 10.1007/s12298-021-00955-x

Ramage, C. M., and Williams, R. R. (2002). Mineral nutrition and plant morphogenesis. Cell. Dev. Biol. Plant 38, 116-124. doi: 10.1079/IVP2001269

Reed, B. M., Wada, S., DeNoma, J., and Niedz, R. P. (2013). Mineral nutrition influences physiological responses of pear in vitro. In Vitro Cell. Dev. Biol-Plant 49, 699-709. doi: 10.1007/s11627-013-9556-2

Salazar-Vega, K. S., Pillalaza Montalvo, S. A., and Vaca-Suquillo, I. (2022). The effect of ascorbic and citric acids in the in vitro establishment of Solanum betaceum to prevent phenolic oxidation. In: Communication, Smart Technologies and Innovation for Society, Smart Innovation, Systems and Technologies. Volume 252, ed. Rocha, A., Lopez-Lopez, P. C., SalgadoGuerrero, J. P. (Springer, Singapore, Technol. Innov. Soc.) p. 199-205. doi: 10.1007/978-981-16-4126-8_19

Shi, X., Yang, L., Yan, G., and Du, G. (2017). Medium pH between 5.5 and 7.5 has minimal effects on tissue culture of apple. HortScience 52, 475-478. doi: 10.21273/HORTSCI11443-16

Silva, T. D., Chagas, K., Batista, D. S., Felipe, S. H. S., Louback, E., Machado, L. T., et al. (2019). Morphophysiological in vitro performance of Brazilian ginseng (Pfaffia glomerata (Spreng.) Pedersen) based on culture medium formulations. In Vitro Cell. Dev. Biol. Plant 55, 454-467. doi: 10.1007/s11627-01910003-9

Skirycz, A., De Bodt, S., Obata, T., De Clercq, I., Claeys, H., De Rycke, R., et al. (2010). Developmental stage specificity and the role of mitochondrial metabolism in the response of Arabidopsis leaves to prolonged mild osmotic stress. Plant Physiol. 152, 226-244. doi: 10.1104/pp.109.148965
Teixeira da Silva, J. A., Nezami Alanagh, E., Barreal, M. E., Kher, M. M., Wicaksono, A., Gulyás, A., et al. (2020). Shoot tip necrosis of in vitro plant cultures: a reappraisal of possible causes and solutions. Planta. 252:47. doi: 10.1007/s00425-020-03449-4

Thorpe, T., Stasolla, C., Yeung, E. C., de Klerk, G. -J., Roberts, A., and George, E. F. (2008). The components of plant tissue culture media II: Organic additions, osmotic and $\mathrm{pH}$ effects, and support systems. In: Plant propagation by tissue culture. 3rd edition, Volume 1, The background, ed. George, E. F., Hall, M. A., de Klerk, G. J. (Springer, Dordrecht, The Netherlands) p. 115-173.

Yuan, F., Guo, J., Shabala, S., and Wang, B. (2019). Reproductive physiology of halophytes: current standing. Front. Plant Sci. 9:1954. doi: $10.3389 /$ fpls.2018.01954

Conflict of Interest: The authors declare that the research was conducted in the absence of any commercial or financial relationships that could be construed as a potential conflict of interest.

Publisher's Note: All claims expressed in this article are solely those of the authors and do not necessarily represent those of their affiliated organizations, or those of the publisher, the editors and the reviewers. Any product that may be evaluated in this article, or claim that may be made by its manufacturer, is not guaranteed or endorsed by the publisher.

Copyright (C) 2022 Doungous, Al-Khayri and Kouassi. This is an open-access article distributed under the terms of the Creative Commons Attribution License (CC BY). The use, distribution or reproduction in other forums is permitted, provided the original author(s) and the copyright owner(s) are credited and that the original publication in this journal is cited, in accordance with accepted academic practice. No use, distribution or reproduction is permitted which does not comply with these terms. 